Relations industrielles

Industrial Relations

\title{
A Note on Industrial Conflict in British Columbia's Construction Industry
}

Joseph B. Rose

Volume 31, numéro 2, 1976

URI : https://id.erudit.org/iderudit/028709ar

DOI : https://doi.org/10.7202/028709ar

Aller au sommaire du numéro

\section{Éditeur(s)}

Département des relations industrielles de l'Université Laval

ISSN

0034-379X (imprimé)

1703-8138 (numérique)

Découvrir la revue

Citer cet article

Rose, J. B. (1976). A Note on Industrial Conflict in British Columbia's

Construction Industry. Relations industrielles / Industrial Relations, 31(2),

309-315. https://doi.org/10.7202/028709ar

Tous droits réservés (C) Département des relations industrielles de l'Université Laval, 1976
Ce document est protégé par la loi sur le droit d'auteur. L'utilisation des services d'Érudit (y compris la reproduction) est assujettie à sa politique d'utilisation que vous pouvez consulter en ligne.

https://apropos.erudit.org/fr/usagers/politique-dutilisation/ 
H. KASPER, (1967). "The Asking Price of Labour and the Duration of Unemployment. "Review of Economics and Statistics, vol. 49, no. 2, May 1967, pp. 965-972.

K. LEWIN, (1944) et al., "Level of Aspiration» in J.M. Hunt(ed). Personality and the Behavior Disorders; New York: Ronald Press.

D.I. MACKAY, (1972). «After the Shake-Out». Oxford Economic Papers, vol. 24, no. 1, March 1972, pp. 89-110.

J.J., McCALL, (1970). «Economics of Information and Job Search». Quarterly Journal of Economic's, vol. 84, no. 1, February 1970, pp. 113-125.

D.T. MORTENSEN, (1970). «Job Search, the Duration of Unempioyment and the Phillips Curve». American Economic Review, vol. 60, no. 5, December 1970, pp. 847-862.

S. ROTTENBERG, (1956). «On choice in Labor Markets». Industrial and Labor Relations Review, vol. 9, no. 2, January 1956, pp. 183-199.

J. SEXTON, (1974). Blue-Collar Workers Displaced by Complete and Permanent Plant Shutdowns - The Quebec Experience. Unpublished Ph. D. Dissertation. Cornell University.

\title{
A NOTE ON INDUSTRIAL CONFLICT IN BRITISH COLUMBIA'S CONSTRUCTION INDUSTRY
}

\author{
Joseph B. Rose
}

Since the publication of the Goldenberg inquiry into construction labour relations in Ontario (1962), the industrial relations system in construction has come under increasing scrutiny. ${ }^{1}$ Studies by Goldenberg and Crispo ${ }^{2}$, Woods ${ }^{3}$ and Rose ${ }^{4}$ have explored such topics as the structure, performance and issues of collective bargaining, the certification process, and the accreditation of contractor associations.

J. B. Rose, Assistant Professor, School of Administration, University of New Brunswick, Fredericton, N.B.

1 Report of the Royal Commission on Labour-Management Relations in the Construction Industry, H. Carl Goldenberg, Commissioner, Ontario, 1962.

2 H. Carl GOLDENBERG and John H. G. CRISPO, eds., Construction Labour Relations, Ottawa, Canadian Construction Association, 1968.

3 Report of the Commission of Enquiry into Industrial Relations in the Nova Scotia Construction Industry, H. D. Woods, Commissioner, Halifax, Nova Scotia Department of Labour, 1970.

4 Joseph B. ROSE, Report on Accreditation and the Construction Industry, Fredericton, New Brunswick Department of Labour, 1972. 
Recently, a new study was published, which examines labourmanagement relations in British Columbia's construction industry. ${ }^{5}$ The inquiry was commissioned because of the growing concern over the disruptive effects of industrial strife on the province's economy. The major purpose of the study was to examine ways of stabilizing construction labour relations and improving the climate for industrial peace. The commission's terms of reference included studying: (1) ways of improving bargaining structure and reforming accreditation legislation; (2) the problems of organizing employees; and (3) the impact of national agreements on collective bargaining in the province.

The present commentary reviews two of the major components of the study. The first section explores the methodological problems involved in analyzing such concepts as countervailing power and accreditation in terms of statistical measures of industrial conflict. This is followed by an assessment of the Report's recommendations for improving bargaining structure in B. C.'s construction industry.

\section{COUNTERVAILING POWER, ACCREDITATION AND STRIKES}

The Report attempts to give some indication of «the extent of countervailing power in employer-employee relations » by examining strike and lockout statistics between 1956 and 1974. The data shows that 241,686 man-days were lost between 1954 and 1969, a mere one-tenth of the man-days lost between 1970 and 1974 (2,551,714 man-days lost). ${ }^{6}$ Unquestionably the 1970's have been marked by bitter labour strife, but do these events logically produce the following conclusion?

A review of the man-days of work delayed over the period 1956 and including 1969, seems to compel one to conclude that labour relations in the construction industry, up until the accreditation of CLRA were relatively good. At the very least, it can be said that the many years from 1956 to 1970 that were effectively free of work stoppages do not seem to indicate some sort of bargaining imbalance. ${ }^{7}$

The Report goes on to compare the time lost due to strikes and lockouts in Ontario and British Columbia by noting:

In terms of strikes and lockouts, this Province possesses a much more unsatisfactory record of time-loss than Ontario. Ontario has an organized construction labour force that is over twice the size of this Province's and yet has experienced only a total of 2,129,759 man-days of work delayed in the period 1970 to 1974 in contrast to the comparable B.C. figure of $2.584,271$ man-days. A primary reason is the existance of relatively smaller accredited bargaining units in Ontario. ${ }^{8}$

5 First Report, Special Commission of Inquiry into British Columbia Construction, James Kinnaird, Commissioner, Victoria, B. C. Department of Labour, 1975.

6 Ibid., p. 42.

7 Ibid.

8 Ibid., p. 43. 
These conclusions do not stand up under scrutiny. Among the most notable shortcomings of the Report's analysis of labour-management relations, are: (1) the presumed linear relationship between an imbalance in bargaining power and industrial strife; (2) the failure to understand, accurately report and evaluate the effect of accreditation on industrial conflict; and (3) the failure to make meaningful comparisons of strike data in Ontario and British Columbia. Let us turn to a brief critique of each of these areas.

(1) The question of whether an imbalance in collective bargaining exists can not simply be measured by examining strike and lockout statistics. Most observers believe the building trades hold the balance of power in the construction industry. Foster and Strauss characterize the unions' advantage as follows:

In the first place, most contractor associations are composed of large numbers of small, undercapitalized employers. Prolonged work stoppages may threaten these firms' solvency. Thus pressure builds from within the association to meet the union's demands, particularly since each employer knows that his competition will have to operate under the same conditions. A second important factor is the localized nature of most bargaining relationships. In this situation many union members are frequently able to find work in nearby jurisdictions, thus mitigating the economic pressure on the union to scale down its demands. ${ }^{9}$

Measuring bargaining power must, therefore, consider the costs of agreeing vs. the costs of disagreeing. For contractors, the threat of a strike or an actual strike during peak construction periods can impose a substantial cost of disagreeing. It is not uncommon for contractors to buy labour peace rather than face a work stoppage, and pass on the added costs to the purchasers of construction. It is noteworthy that despite the labour tranquility of the 1960's, construction workers in B.C. improved their relative wage position vis-a-vis workers in other industries, e.g., manufacturing (see Table 1). Similar results have been reported in the United States. ${ }^{10}$ These findings suggest that strike proneness may be but one symptom of an imbalance of power; disproportionate wage increases would appear to be another.

(2) The Report erroneously conveys the impression that the process of accreditation and increased industrial strife are linked. In actual point of fact, the lengthy work stoppage of 1970 (925,000 mandays lost) preceded the accreditation of CLRA. (CLRA was accredited on July 14, 1970, twelve weeks after the work stoppage began). Furthermore, a careful examination of the voluntary nature of accreditation legislation in B.C. casts doubt as to whether it has exerted an independent influence on labour-management conflict. Indeed, accreditation

9 Howard G. FOSTER and George STRAUSS, «Labor Problems in Construction: A Review», Industrial Relations, XI, October, 1972, p. 310.

10 Howard G. FOSTER, «Wages in Construction: Examining the Arguments», Industrial Relations, XI, October, 1972, pp. 336-349. 
TABLE 1

Hourly Earnings in Construction as a Percent of Manufacturing in British Columbia, 1960-1970

$\begin{array}{cccc} & & & \begin{array}{c}\text { Construction As } \\ \text { A Percentage Of } \\ \text { Manufacturing }\end{array} \\ 1960 & \text { Construction } & \text { Manufacturing } & 125.7 \\ 1961 & \$ 2.74 & \$ 2.18 & 123.8 \\ 1962 & 2.76 & 2.23 & 124.1 \\ 1963 & 2.83 & 2.28 & 125.0 \\ 1964 & 2.95 & 2.36 & 126.3 \\ 1965 & 3.17 & 2.47 & 132.4 \\ 1966 & 3.47 & 2.62 & 143.2 \\ 1967 & 3.98 & 2.78 & 142.9 \\ 1968 & 4.30 & 3.01 & 134.1 \\ 1969 & 4.33 & 3.23 & 144.0 \\ 1970 & 5.01 & 3.48 & 147.1\end{array}$

SOURCE: DBS Publication 72-202, Annual Review of Man-Hours and Hourly Earnings

does little more than give CLRA in law what it achieved on a voluntary basis in 1969 .

The increase in labour unrest in the post-CLRA period resulted from many factors. Efforts by CLRA to coordinate and centralize bargaining met stiff resistance from the unions. In 1970, some unions were opposed to voluntarily recognizing CLRA as the contractors' bargaining agent. The lockouts imposed by CLRA in 1970 and 1972, which were in response to the divide-and-conquer tactics of the unions, produced further bitterness. Government attempts to resolve these disputes, including the imposition of compulsory arbitration, only antagonized the building trades and prolonged the work stoppages. Finally, in 1974, the initiation of joint bargaining by ten trades produced another impasse.

The Report considers many of these underlying causes of labour unrest, but fails to perceive the interrelationship of these events. The structure of collective bargaining has been dramatically transformed in the past five years. Since its creation, CLRA has been committed to more centralized collective bargaining. The turmoil which has been experienced in the 1970's appears to be a response to CLRA rather than accreditation. Theoretically accreditation was designed to give employers countervailing power, but in practice its effect has been only minimal. This is because accreditation does not give CLRA control over unionized contractors who have chosen to remain outside the organization. CLRA amply demonstrated its bargaining power as an unaccredited association in 1970, when it employed a three-month lockout of the building trades. 
(3) The comparison of time lost due to strikes and lockouts in Ontario and B.C. is misleading in two respects. Firstly, the period 1970-1974 is not an appropriate time span for comparison. During this period there were three major rounds of negotiations in B.C. (1970, 1972 and 1974), whereas in Ontario, there were only two. In 1975, Ontario's construction industry had to re-negotiate more than 325 collective agreements. Although offical strikes statistics for 1975 have not as yet been published, newspaper accounts of the Ontario negotiations indicated there was an upsurge in labour strife. ${ }^{11}$

A second problem with the analysis is that there is no basis for concluding that smaller accreditation units in Ontario account for differentials in industrial conflict. Experience with accreditation is extremely limited in Ontario. As of December 31, 1973, the Ontario Labour Relations Board had issued 21 accreditation orders for 13 contractor associations (3 in 1971, 5 in 1972 and 13 in 1973). Consequently, most of these contractor associations have either never bargained or have bargained only once as an accredited body between 1970 and 1974. In addition, the number of accreditation orders issued during this period cover only a small proportion of the potential bargaining units in the province (predominantly among mechanical contractors).

Even if we overlook these shortcomings, what can be derived from such a comparison of strike statistics? Are we to assume that aggregate measures of man-days lost are an accurate reflection of the economic impact of strikes? In Ontario, where bargaining structure is more decentralized, a strike by one trade can shut down all unionized construction in a particular locality, e.g., metropolitan Toronto. Regardless of how long a dispute continues, the total number of workers on strike and man-days lost could be insignificant in comparison to the time lost by construction workers refusing to cross picket lines. In conclusion, the Report's analysis of interprovincial strike data is incomplete on two scores: it fails to consider the significance of such factors as the ripple effect of industrial conflict and its inferences about accreditation can not be substantiated.

\section{IMPROVING BARGAINING STRUCTURE}

Despite some of the Report's conclusions about accreditation, it strongly endorses centralized collective bargaining in construction, even if it requires legislative action. The building trades would be required to recognize construction as an integrated industry, in which common objectives must be coordinated in the public interest. To achieve this end, it was recommended that individual building trades be required to: (1) establish a provincial council of its local unions; (2) join the British Columbia and Yukon Territory Building and Construction trades Council; (3) conduct its collective bargaining through the Council.

11 "A Long Summer of Labor Discontent: 193 Strikes Involving 40,000 Workers », Globe and Mail, July 10, 1975, pp. I, 2. 
If the unions are not prepared to do this voluntarily, the Report recommends that it be made compulsory. It further recommends that the Council be formally recognized in law as the umbrella organization representing construction unions.

On the employer side, it was suggested that trade association bargaining be pursued with CLRA acting in the same capacity as the Provincial Building Trades Council. This could be achieved within the existing organizational structure of CLRA. The Report recognizes that CLRA has demonstrated «industrial relations maturity» and that there is no need to revise accredititation legislation. Although multi-trade bargaining is not ruled out, the Report strongly endorses trade-by-trade bargaining at the provincial level as the best means for resolving trade issues and promoting harmonious labour relations. These proposals are remarkably similar to those advanced by the Construction Labour Relations Association of Ontario in a recent brief to the Ontario government. ${ }^{12}$

Certainly there is room to debate whether these recommendations are more advantageous than province-wide, multi-trade bargaining. These arguments aside, the Report's proposals do provide a basis for improving labour-management relations. They consistently stress the need for unions to view labour relations from a more integrated perspective and strongly discourage independent action. Besides requiring individual unions to bargain through the Provincial Building Traders Council, the Report proposes that unions wishing to «go it allone» be prohibited by law from picketing integrated work sets. The poor record of labour unrest in the 1970's may prove to be the only incentive the parties need to adjust to these proposed legislative and organizational changes. If not, the growing challenge of right-to-work and own-account construction along with need to protect the interests of the public and clients, should stimulate a more cooperative labour relations environment.

\section{CONCLUSION}

I am of two minds about this Report. Although the Commission has done a credible job of collecting data, the analysis of this material is plagued by numerous shortcomings. What is most disturbing is the failure of the Report to fully appreciate the complexities of assessing the impact of accreditation legislation on the construction industrial relations system. The proposition that increases in industrial conflict are associated with accreditation remains unproven. Even if we accepted this proposition, it is unclear why the Commission failed to recommend that accreditation be repealed.

12 Wilfred LIST, "Province-Wide Bargaining Sought by CLRA in Brief to Commission", Globe and Mail, February 10, 1976, p. B2. 
Finally, it is quite surprising that a study characterized by these and other methodological limitations can produce such intriguing, and indeed, credible recommendations for improving construction labour relations. It will be interesting to observe whether labour, management and the government will be able to transform these proposals into a course of action.

\title{
FULL EMPLOYMENT AND SOCIAL POLICIES : A EUROPEAN LESSON?
}

\author{
Klaus WeIERMAIR
}

Most industrialized European countries have, over the past decade, shown an appreciably better performance of their labour markets than the U.S. or Canada when measured in such terms as rates of unemployment. Even at times of recession such as prevailing at the present, the unemployment rates on an annual basis rarely climb over $3-4 \%$. At the same time, many of these countries, but notably Sweden and West-Germany, have experienced almost an explosion of social reforms and labour market interventions of one kind or another, which orthodox economists in this country would condemn as socialist, inflationary and of questionable impact to the efficient operation of labour markets.

It is difficult, if not even impossible, to exactly evaluate and compare the efficiency and efficacy of labour market policies across such countries as the U.S., Canada, Sweden or West-Germany due to the inherent differences in production and labour market conditions, different patterns of growth and international trade. Nevertheless, it is possible and certainly useful to describe and analyze basic philosophical differences of labour market policies with respect to the development and adjustment of manpower in a complex and dynamically changing economic environment.

The problem of the right philosophy or if you want the right policy for interventions in the labour market is predetermined by the way in which one perceives of and analyzes such problems. Before discussing what Europeans undertake to bring their labour markets into order, let me, therefore, postulate and explain why labour markets may not function properly in advanced economies, in the first place.

- Modern economies are dominated by large structural changes which have such an enormous repercussion on labour markets that interventions will become necessary sooner or later.

* K. Weiermair Associate Professor, Faculty of Administrative Studies, York University, presently on leave with the International Institute of Management WestBerlin, Germany. 